\title{
Demographic Variables and Its Effect on Emotional Intelligence: A Study on Indian Service Sector Employees
}

\author{
Pooja Pooja Pranab Kumar \\ Department of Management, Birla Institute of Technology, Extension Centre, Lalpur, Ranchi, Jharkhand, India
}

\section{Key Words}

Trait emotional intelligence - Gender · Age · Work experience $\cdot$ Educational level · Management level

\begin{abstract}
In past few decades, emotional intelligence (EI) has gained much popularity worldwide. Intelligence quotient alone is not enough in today's age for achieving success and hence for developing a person's ability, the fields of psychology and neurosciences have highlighted the importance of El, which is a person's response toward feelings and emotions. In this study, relationship of various demographic variables with El, as measured by Trait Emotional Intelligence Questionnaire-Short Form, has been highlighted. The study has been conducted on a sample of 424 employees belonging to the Indian service sector. The results showed that demographic variables have an impact over El. Organizations can take a cue from the study and adhere to diversity management practices to ensure financial gains and growth.
\end{abstract}

(c) 2016 S. Karger AG, Basel

\section{Introduction}

The term 'emotional intelligence (EI)' first appeared in 1985 [1] in a doctoral thesis. Prior to it, the term was used by Leuner [2]. The concept came in existence when a work on multiple intelligences including 'interpersonal intelligence' and 'intrapersonal intelligence' were highlighted [3]. To clarify further, it was [4] postulated that EI involves the ability to perceive, appraise and express emotion, the ability to access and/or generate emotional knowledge and the ability to regulate emotion to promote emotional and intellectual growth. It was also [5] theorized that EI is an important indicator of success in one's professional and personal life. Petrides et al. [6] introduced the 'Trait EI theory' and defined EI as 'a constellation of emotional self-perceptions located at the lower levels of personality', which encompasses behavioral dispositions and self-perceived abilities. Emotions are very infectious, and even a single person can influence the emotions of others. Moreover, since the majority of the work to be performed in organizations involves interacting with people, it becomes even more important that EI must be given due concern. People who are well aware of their emotions and can judge other's emotions well are found be more effective in their jobs [7]. The present study focuses on the employees working in the Indian service sector.

The contribution of this sector in the country's GDP was $56.8 \%$ during the years $2010-2011$ [2]. The projections for 2014-2015 show the value to reach beyond $60 \%$ [8]. Thus, addressing the issues of the sector can lead to the reaping of multiple benefits for both itself as well as the economy. For decades following the independence of

\section{KARGER}

E-Mail karger@karger.com

www.karger.com/aon
(C) 2016 S. Karger AG, Basel

0972-7531/16/0231-0018\$39.50/0
Pooja Pooja

Research Scholar, Department of Management

Birla Institute of Technology

Lalpur, Ranchi, Jharkhand 834001 (India)

E-Mail pooja.kh86@gmail.com 
India in 1947, population of the country was a liability but now it is its potential asset [8]. This demographic resource can be tapped and their multiple, cognitive and EI can be utilized to harvest benefits for the economy. The area of EI is influenced by a variety of factors such as biological, social and psychological. The present study reviews the effect of demographic variables on EI by hypothesizing it as follows:

Hypothesis 1 (H01). There is no significant difference between the EI values of male and female employees of the service sector in India.

Hypothesis 2 (H02). There is no significant difference between the EI values of the employees of the service sector in India across various age groups.

Hypothesis 3 (H03). There is no significant difference between the EI values of the employees of the service sector in India having different educational qualifications.

Hypothesis 4 (H04). There is no significant difference in the levels of EI with varying experience levels of the service sector employees in India.

Hypothesis 5 (H05). There is no significant difference in the levels of EI across varying management levels in India.

\section{Method}

The present study comprises a sample of 424 employees from the Indian service sector. Sampling technique used was stratified random sampling. As per the Ministry of Statistics and Programme Implementation [3], the industries in the services sector are the following:

(1) Hotels and restaurants

(2) Transport including tourist assistance activities as well as activities of travel agencies and tour operators

(3) Storage and communication

(4) Banking and insurance

(5) Real estate and ownership of dwellings

(6) Business services including accounting; software development; data processing services; business and management consultancy; architectural, engineering and other technical consultancies and advertisement and other business services

(7) Education

(8) Medical and health

(9) Retail

- www.indiabudget.nic.in

- www.ibef.org/industry/services.aspx

- www.mopsi.com

The study was conducted for an overall period of 18 months using an internationally accepted measurement tool - Trait Emotional intelligence Questionnaire-Short Form (TEIQueSF) - that was developed by Petrides et al. [6]. The EIs of the respondents were measured in Psychometric labs, University
Table 1. Sample distribution of the study

\begin{tabular}{|c|c|}
\hline \multicolumn{2}{|l|}{ Gender } \\
\hline Male & 246 \\
\hline Female & 178 \\
\hline \multicolumn{2}{|l|}{ Age, years } \\
\hline $20-30$ & 146 \\
\hline $31-40$ & 133 \\
\hline $41-50$ & 48 \\
\hline $51-60$ & 97 \\
\hline \multicolumn{2}{|c|}{ Education qualification } \\
\hline Technical & 202 \\
\hline Non-technical & 222 \\
\hline \multicolumn{2}{|c|}{ Work experience, years } \\
\hline $0-5$ & 103 \\
\hline $6-10$ & 126 \\
\hline $11-15$ & 83 \\
\hline $16-20$ & 74 \\
\hline 20 and above & 38 \\
\hline \multicolumn{2}{|l|}{ Management level } \\
\hline Lower & 137 \\
\hline Middle & 184 \\
\hline Upper & 103 \\
\hline \multicolumn{2}{|l|}{ Industry } \\
\hline Tourism & 37 \\
\hline IT/ITES & 65 \\
\hline Real estate & 40 \\
\hline Health & 43 \\
\hline Education & 41 \\
\hline Media & 59 \\
\hline Retail & 40 \\
\hline Banking & 65 \\
\hline Hospitality & 34 \\
\hline \multicolumn{2}{|c|}{ Geographical region } \\
\hline East & 159 \\
\hline West & 86 \\
\hline North & 93 \\
\hline South & 86 \\
\hline
\end{tabular}

IT = Information technology; ITES $=$ IT-enabled services.

College, London. The response to the items on TEIQue-SF are made on a 7-point Likert scale where 1 is 'strongly disagree' and 7 is 'strongly agree'. The negative items on the questionnaire are reverse scored. It is a self-administered questionnaire and does not require the presence of researcher. Hence, it is very useful as it is a cost-effective method and is convenient for the respondents because it could be filled out whenever they have time and has geographic flexibility.

Demographic information such as gender, age, experience, management level, geographical region and industry of the respondents was also sought. The TEIQue-SF that was used to measure EI was adapted to suit the Indian context. The tool initially comprised 30 questions of which 11 questions were removed after conducting a pilot study on a small population of 50 professionals from the Indian service sector, and the reliability (Cronbach's alpha) was found to be as 0.716 , which is an acceptable reliability coefficient 2 . The overall sample distribution is illus- 
Table 2. Test for normality of the data

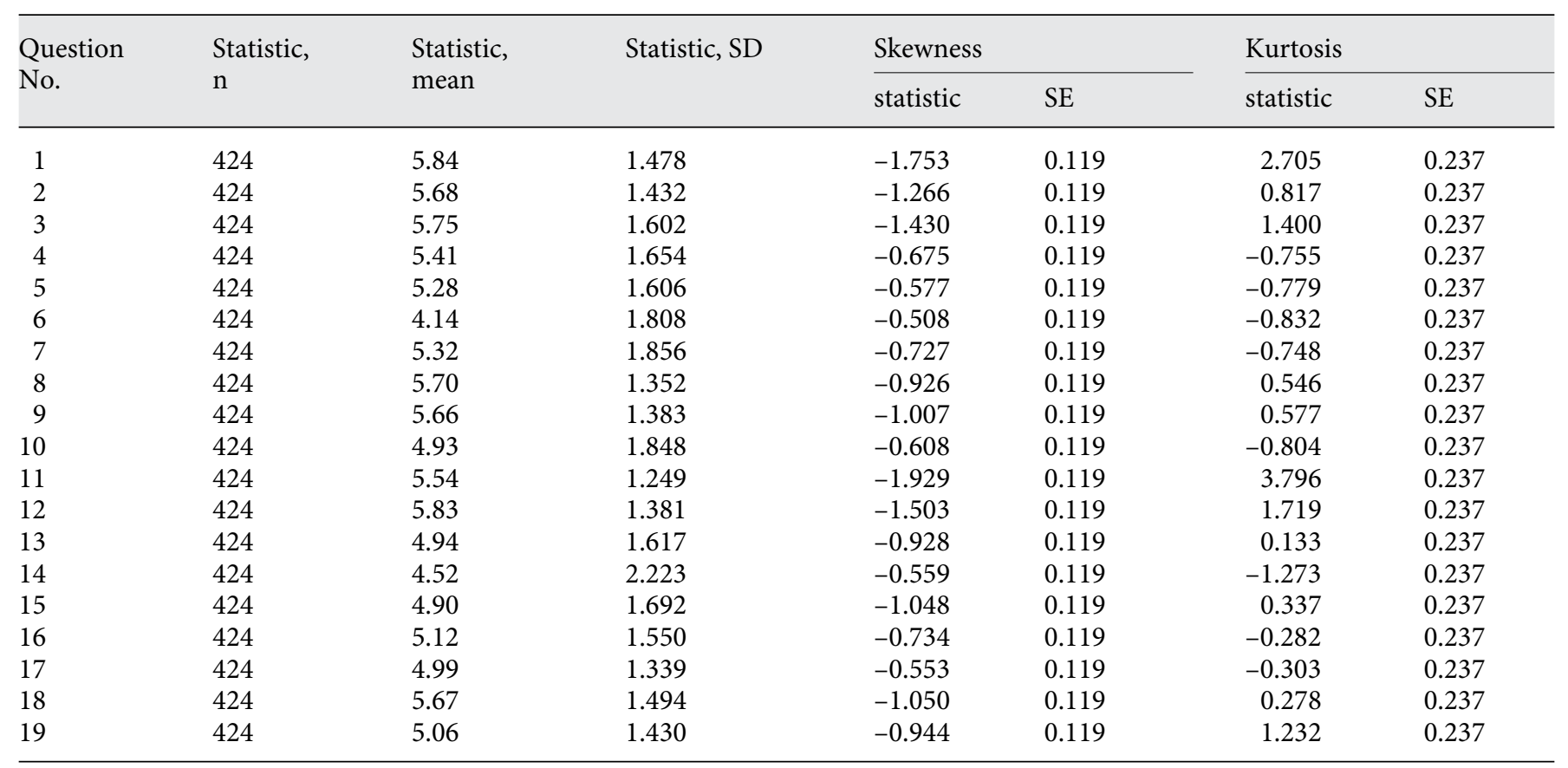

$\mathrm{n}=$ Total number of respondents.

trated in table 1 . The value of skewness for all the 19 items of the EI scale were found to be lying in the range of -0.508 and -1.929 , and the kurtosis value for all the 19 items were found to lie in the range of -0.282 and 3.796 (table 2). For sample sizes, which are more than 300 , the absolute skew value larger than 2 or an absolute kurtosis value larger than 7 are used as the reference values for determining non-normality of the data 16 . Since, the values are in the specified range in the present study, the assumption of normality of data has been met. The data analysis is done using the SPSS version 21.0. Since the data satisfy the test of normality, parametric tests such as the independent $t$ test and analysis of variance (ANOVA) were used to find the relation among the variables.

\section{Results}

\section{Gender}

An independent $t$ test was performed in order to find significant difference between the EI values of male and female employees of the service sector. The findings are illustrated in table 3. Significance value for Levene's test is $<0.05$; hence, we read from the second row, which has the significant (2-tailed) value of $<0.05$, and thus reject the hypothesis $\mathrm{H} 01$ and conclude that female have higher values of EI with a mean score of 101.96 as compared to males with a mean score of 99.04 .
Age

In order to find out whether the employees of various age groups have varying EI values or not, ANOVA was used. Results are illustrated in table 4 and figure 1 . It was concluded that the significant (2-tailed) value should be $<0.05$ at $95 \%$ CI for the group variances to be treated as unequal. Hence, the hypothesis $\mathrm{H} 02$ was rejected and it was inferred that EI values differs and increases according to age with employees belonging to the age group of 5160 years thus scoring the highest in the Indian service sector.

\section{Educational Qualification}

ANOVA was used in order to find out whether the employees of varying qualifications have varying EI values. Results are illustrated in table 5 and figure 2 . It was found that the significant (2-tailed) value should be $<0.05$ at $95 \%$ CI for the group variances to be treated as unequal. Hence, the hypothesis, $\mathrm{H} 03$ was rejected and it was thus inferred that EI values differ according to qualification with employees having non-technical education being more emotionally intelligent than their technical counterparts in the Indian service sector. In the present study, the employees having technical education had MTech, BTech, MCA, BCA as their qualifications 
Table 3. Independent $t$ test for effect of gender on EI

a Descriptive statistics for the EI values of male and female employees

\begin{tabular}{llrrr}
\hline EI & $\mathrm{n}$ & Mean & SD & SE, mean \\
\hline Gender & & & & 0.704 \\
$\quad$ Male & 246 & 99.04 & 11.046 & 0.810 \\
Female & 178 & 101.96 & 10.808 & 0 \\
\hline
\end{tabular}

$\mathrm{n}=$ Number of respondents.

b Independent samples test

\begin{tabular}{|c|c|c|c|c|c|c|c|c|c|}
\hline EI & $\mathrm{F}$ & sig. & $\mathrm{t}$ & d.f. & $\begin{array}{l}\text { sig. } \\
\text { (2-tailed) }\end{array}$ & $\begin{array}{l}\text { mean } \\
\text { difference }\end{array}$ & $\begin{array}{l}\text { SE } \\
\text { difference }\end{array}$ & lower & upper \\
\hline $\begin{array}{l}\text { Equal variances assumed } \\
\text { Equal variances not assumed }\end{array}$ & 0.199 & 0.656 & $\begin{array}{l}-2.711 \\
-2.720\end{array}$ & $\begin{array}{l}422 \\
386.264\end{array}$ & $\begin{array}{l}0.007 \\
0.007\end{array}$ & $\begin{array}{l}-2.920 \\
-2.920\end{array}$ & $\begin{array}{l}1.077 \\
1.073\end{array}$ & $\begin{array}{l}-5.037 \\
-5.030\end{array}$ & $\begin{array}{l}-0.803 \\
-0.810\end{array}$ \\
\hline
\end{tabular}

$\mathrm{F}=\mathrm{F}$ statistic (group variance/within group variance); sig. = significance value; d.f. = degrees of freedom; $\mathrm{t}=\mathrm{t}$ value $=$ mean difference/SE.

whereas employees having non-technical education had MBA, BBA, Law, humanities, arts, etc. as their qualifications.

\section{Work Experience}

ANOVA was used in order to find out whether the employees of varying experience levels have varying EI values. Results are illustrated in table 6 and figure 3 . It was noticed that the significance (2-tailed) was $<0.05$ at $95 \%$ $\mathrm{CI}$ and hence the group variances were treated as unequal. Hence, hypothesis H04 was rejected and it was thus inferred that EI values differs according to work experience with employees having 16-20 years of work experience being more emotionally intelligent. An interesting finding reported here was that EI value increases with increase in number of years of work experience and reached its peak when the employee had worked for around 16-20 years, and after that, further increase in the years of work experience caused the EI value to fall for the employees belonging to service sector in India.

\section{Management Level}

ANOVA was used in order to find out whether the employees of varying management levels have varying EI values. Results are illustrated in table 7 and figure 4 . The significance (2-tailed) was found to be $<0.05$ at $95 \%$ CI for the group variances to be treated as unequal. Hence, hypothesis $\mathrm{H} 05$ was rejected and it was thus inferred that EI values differs according to management level and increased as the employee belonging to Indian service sector climbed up the organizational hierarchy.

\section{Discussions}

On the basis of analysis of data collected, it can be understood that EI has its importance in the Indian service sector. The study provides an empirical analysis of the relationship between various demographic variables and their effect on the EI values of the employees of the Indian service sector. The results showed that there are significant differences in the levels of EI with the demographic variables thus chosen for the study. The study has a number of important findings. First, it confirms that female employees are more emotionally intelligent than male employees. The result thus obtained is consistent with the findings of a previous study [9] where it was concluded that there is a difference in the mean scores of male and female employees with females scoring more. It was also postulated $[7,10,11]$ that females score more on the EI scale. Since the past few decades, women are entering the workforce in increasing numbers. They are proving their 
Table 4. ANOVA for difference between the EI values of the employees of the service sector in India across various age groups

\begin{tabular}{|c|c|c|c|c|c|}
\hline \multirow[t]{2}{*}{ EI } & \multicolumn{5}{|l|}{ ANOVA } \\
\hline & $\begin{array}{l}\text { sum of } \\
\text { squares }\end{array}$ & d.f. & $\begin{array}{l}\text { mean } \\
\text { square }\end{array}$ & $\mathrm{F}$ & sig. \\
\hline Between groups & $12,171.744$ & 3 & $4,057.248$ & 43.385 & 0.000 \\
\hline Within groups & $39,277.141$ & 420 & 93.517 & & \\
\hline Total & $51,448.884$ & 423 & & & \\
\hline
\end{tabular}

$\mathrm{F}=\mathrm{F}$ statistic (group variance/within group variance); sig. = significance value; d.f. $=$ degrees of freedom.

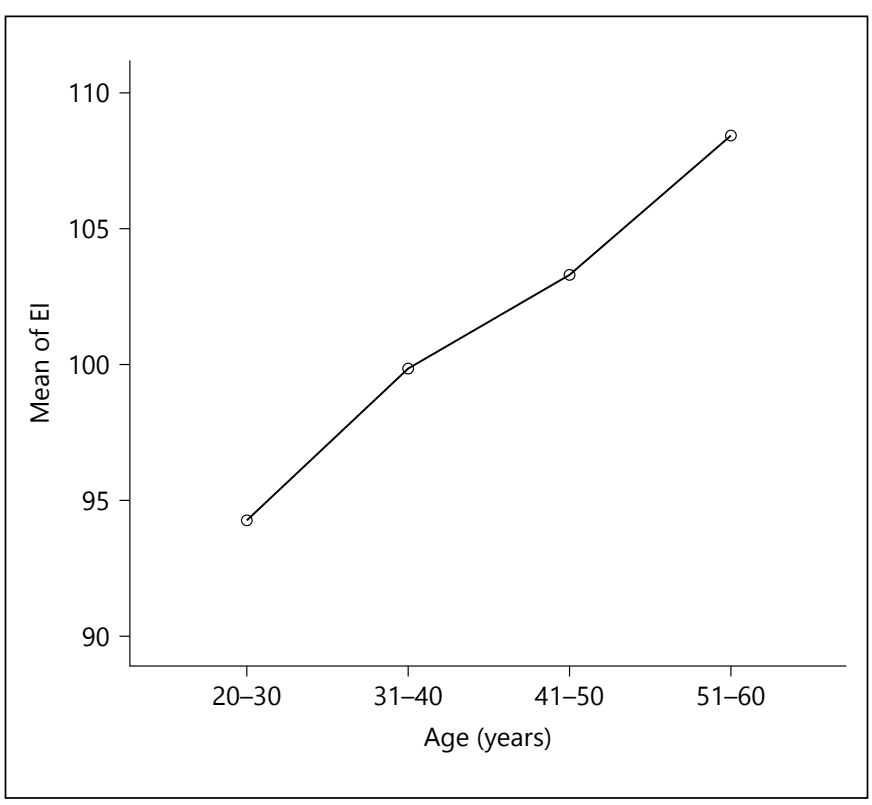

Fig. 1. Mean plot of EI for age.

worth as managers and executives in organizations. Initially, they did face discrimination from the society as well as from their male counterparts but slowly they were accepted, although the practice still persists. The phenomena is described as 'glass ceiling' [12], which is a 'transparent barrier preventing women from ascending management hierarchies'. This discrimination is mostly on the grounds of compensation, promotion, etc. The findings of the current study might help organizations and their policy makers to make the hiring and promoting policies more transparent and easier for female employees.

Age was found to be positively associated with EI. The finding was in consistency with a previous study [13]
Table 5. ANOVA for difference between the EI values of the employees of the service sector in India for different educational qualifications

\begin{tabular}{llrlll}
\hline EI & \multicolumn{1}{l}{ ANOVA } & & & & \\
\cline { 2 - 6 } & $\begin{array}{l}\text { sum of } \\
\text { squares }\end{array}$ & d.f. & $\begin{array}{l}\text { mean } \\
\text { square }\end{array}$ & F & sig. \\
\hline Between groups & $2,889.698$ & 1 & $2,889.698$ & 25.113 & 0.000 \\
Within groups & $48,559.187$ & 422 & 115.069 & & \\
Total & $51,448.884$ & 423 & & & \\
\hline
\end{tabular}

$\mathrm{F}=\mathrm{F}$ statistic (group variance/within group variance); sig. = significance value; d.f. = degrees of freedom.

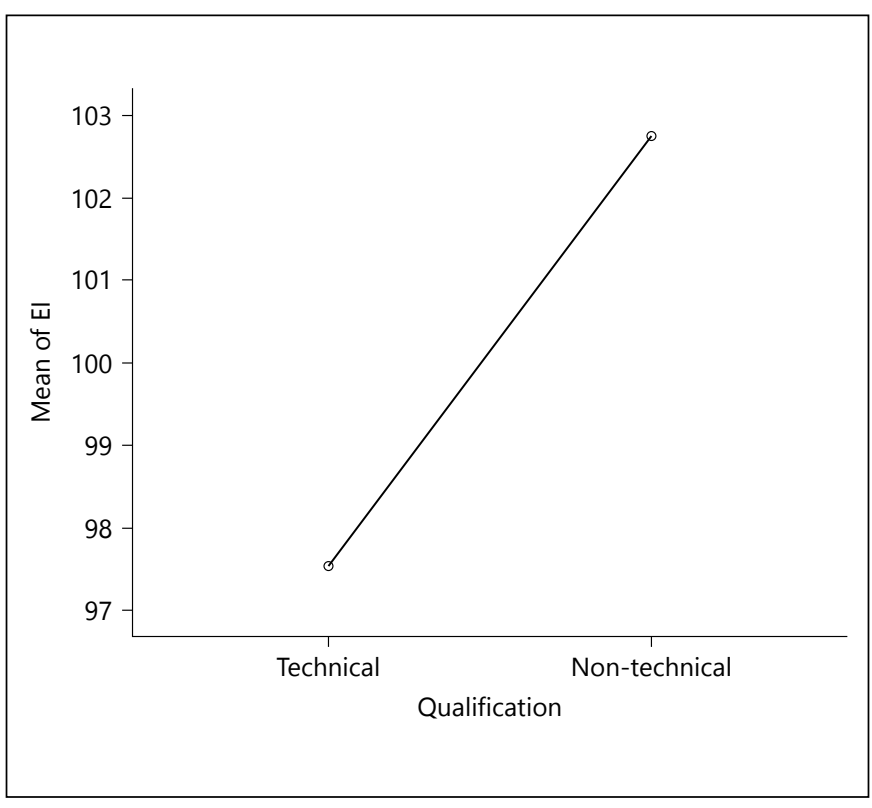

Fig. 2. Mean plot of EI for educational qualification.

where it was found that age correlates positively with EI across different job situations. The present study will help the employees and organizations take a cue about in which age intervals developing and increasing EI abilities should be given preference. The finding will be typically valuable to the organizations and their top management and help them in the hiring process, employee development, coaching and training programs. The probable reason for the non-technically qualified employees scoring more on the EI scale can be attributed to the fact that these employees have the need to interact with people of diverse backgrounds both within as well as outside the organization as a part of their job, which results in them acquiring 
Table 6. ANOVA for difference between the EI values of the employees of the service sector in India for varying experience levels

\begin{tabular}{llrlll}
\hline EI & ANOVA & & & & \\
\cline { 2 - 6 } & $\begin{array}{l}\text { sum of } \\
\text { squares }\end{array}$ & d.f. & $\begin{array}{l}\text { mean } \\
\text { square }\end{array}$ & F & sig. \\
\hline Between groups & $12,665.921$ & 4 & $3,166.480$ & 34.210 & 0.000 \\
Within groups & $38,782.964$ & 419 & 92.561 & & \\
Total & $51,448.884$ & 423 & & & \\
\hline
\end{tabular}

$\mathrm{F}=\mathrm{F}$ statistic (group variance/within group variance); sig. = significance value; d.f. = degrees of freedom.

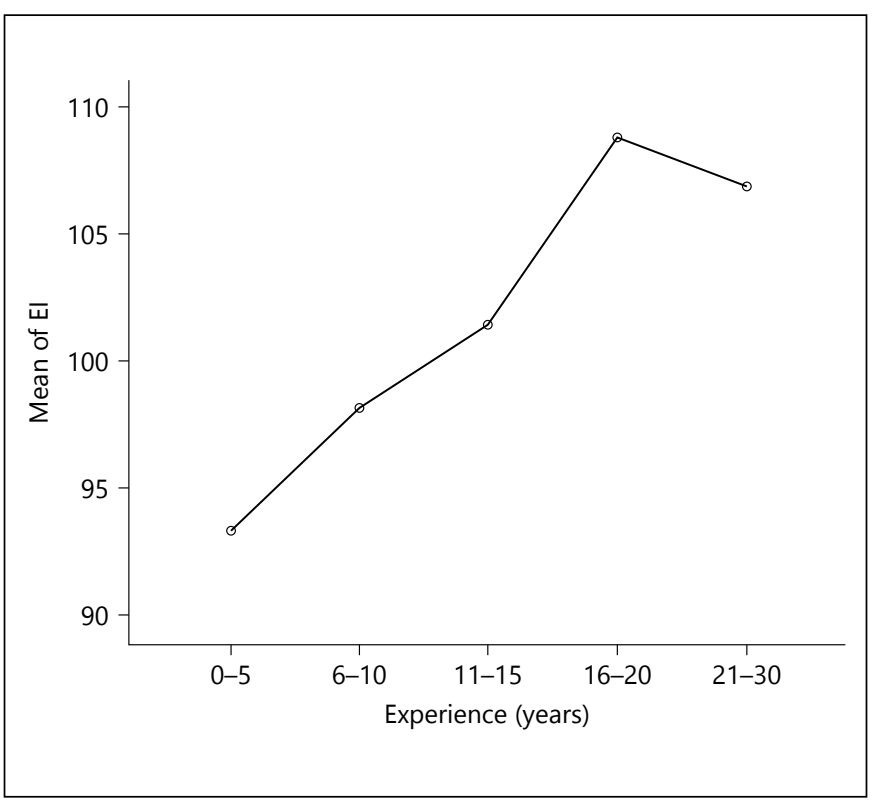

Fig. 3. Mean plot of EI for work experience.

interpersonal skills and thus becoming better at gauging the other person's emotion. The finding is supported on the grounds that employees with non-professional degree score high on some of the EI capabilities, which can be attributed to the nature of non-technical job performed by them, their ability to experiment and explore the opportunities [14].

The trend noticed in the work experience context might be due to the fact that after having an experience of so many years at work, the job of the employees in that particular segment (21-30 years) requires less time interacting with employees and staff, and hence they have limited opportunities for feedback from their subordinates
Table 7. ANOVA for difference between the EI values of the employees of the service sector in India belonging to varying management levels

\begin{tabular}{llrlll}
\hline EI & \multicolumn{1}{l}{ ANOVA } & & & & \\
\cline { 2 - 6 } & $\begin{array}{l}\text { sum of } \\
\text { squares }\end{array}$ & d.f. & $\begin{array}{l}\text { mean } \\
\text { square }\end{array}$ & F & sig. \\
\hline Between groups & $11,356.192$ & 2 & $5,678.096$ & 59.624 & 0.000 \\
Within groups & $40,092.692$ & 421 & 95.232 & & \\
Total & $51,448.884$ & 423 & & & \\
\hline
\end{tabular}

$\mathrm{F}=\mathrm{F}$ statistic (group variance/within group variance); sig. = significance value; d.f. = degrees of freedom.

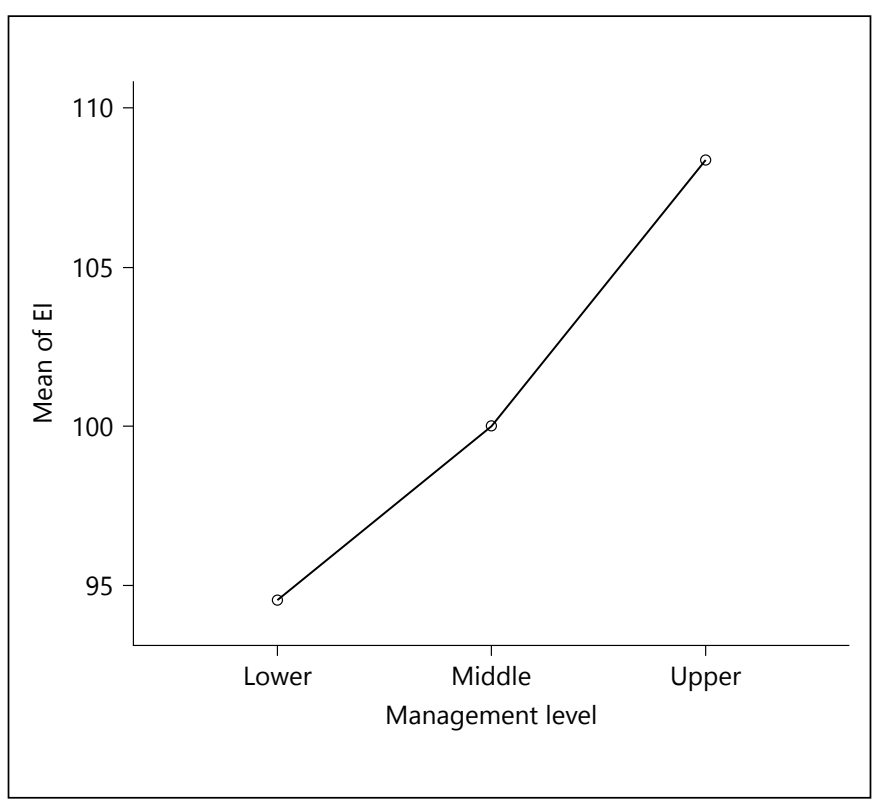

Fig. 4. Mean plot of EI for management level.

and colleagues, which results them in them not being aware of their interpersonal skills and hence are poor at managing EI capabilities.

The reason for the employees belonging to upper management level scoring more on the EI scale might be due to the fact that when employees reach upper management level in their organization, they are required to achieve results through others. They have to aim toward a wider vision, formulate strategies and policies for the organization and influence other employees with their influential leadership. Hence, they are very much required to polish their people skills, which results in making them more emotionally intelligent. A study conducted [15] on proj- 
ect managers concluded that top management level employees have the highest value of EI followed by executive level, middle level and operational level employees and was found to be consistent with the findings of the present study.

The results showed that significant differences exist in the levels of EI for the demographic variables thus chosen for the study. As the organizations of this sector in India are operating in a fiercely competitive environment, it is imperative that the issue of diversity management must be duly taken care of. Dimensions of diversity as per the present research were gender, age, educational qualification, work experience, management level, etc. Indian economy is progressing at a faster pace implying that the challenges are also growing. Just academic excellence and technical expertise cannot ensure success for an individual or an organization. Competency like managing one's emotions is also very crucial. Since there is always a constant pressure on the employees to perform, EI is required to overcome those challenges at the workplace and scale the organization to greater heights. The area of neuroscience dealing with EI can play a vital role in making employees understand and comprehend emotions in a better manner and in adopting a proactive approach toward people with whom they interact.

\section{Authorship Contribution}

Pooja: literature review, data collection, analysis of the data. Dr. Pranab Kumar: topic selection, content selection, organization of the article, editing and proofreading.

\section{References}

1 Payne WL: A Study of Emotion: Developing Emotional Intelligence, Self Integration, Relating to Fear, Pain and Desire, 1985.

2 Leuner B: [Emotional intelligence and emancipation. A psychodynamic study on women]. Prax Kinderpsychol Kinderpsychiatr 1966;15:196-203.

3 Gardner H: Frames of Mind: The Theory of Multiple Intelligences. New York, Basic Book, 1983.

4 Mayer JG, Salovey P: What is emotional intelligence? in Salovey P, Sluyter B (eds): Emotional Development and Emotional Intelligence: Implications for Educators. New York, Basic Books, 1997, pp 3-31.

5 Goleman D: Emotional Intelligence: Why It Can Matter More Than IQ. New York, Bantam Books, 1995.
6 Petrides KV, Pita R, Kokkinaki F: The location of trait emotional intelligence in personality factor space. Br J Psychol 2007;98(pt 2): 273-289.

7 Afolabi AO, Adesina AA: Influence of job frustration, narcissism and demographic variables on attitudes towards professional ethical behavior among Nigerian police officers. Afr J Psychol Study Soc 2006;9:37-45.

8 Nunnaly J: Psychometric Theory. New York, McGraw-Hill, 1978.

9 Pande HS: Evaluating characteristics and emotional intelligence among workers in organizations in the state of Rajasthan. Int Res J 2010;1:3-6.

10 Day AL, Carroll SA: Using an ability-based measure of emotional intelligence to predict individual performance, group performance, and group citizenship behaviors. Pers Individ Dif 2004;36:1443-1458.
11 Grewal D, Salovey P: Feeling smart: the science of emotional intelligence. Am Sci 2005; 93:330.

12 Miller K: Women and leadership and management: progress thus far? in Women in Leadership and Management. Massachusetts, Edward Elgar Publishing, 2006, p 1.

13 Wong CS, Law KS: The effects of leader and follower emotional intelligence on performance and attitude: an exploratory study. Leadersh Q 2002;13:243-274.

14 Anand R, Udayasuriyan G: Emotional intelligence and its relationship with leadership practices. Int J Bus Manag 2010;2:65.

15 Obradovic V, Jovanovic P, Petrovic D, Mihic M, Mitrovic Z: Project managers' emotional intelligence - a ticket to success. Procedia Soc Behav Sci 2013;74:274-284. 